\title{
Extensive sampling and high-throughput sequencing reveal Posidoniomyces atricolor gen. et sp. nov. (Aigialaceae, Pleosporales) as the dominant root mycobiont of the dominant Mediterranean seagrass Posidonia oceanica
}

\author{
Martin Vohník ${ }^{1,2}$, Ondřej Borovec ${ }^{1,2}$, Zuzana Kolaříková', \\ Radka Sudová', Martina Réblová ${ }^{3}$
}

I Department of Mycorrhizal Symbioses, Institute of Botany, Czech Academy of Sciences, Lesni 322, 25243 Pruhonice, Czech Republic 2 Department of Experimental Plant Biology, Faculty of Science, Charles University, Viničná 5, 12844 Prague, Czech Republic 3 Department of Taxonomy, Institute of Botany, Czech Academy of Sciences, Zámek 1, 25243 Prìhonice, Czech Republic

Corresponding author: Martin Vohnik (vohnik@ibot.cas.cz)

Academic editor: Huzefa Raja | Received 23 April 2019 | Accepted 6 June 2019 | Published 26 June 2019

Citation: Vohník M, Borovec O, Kolaříková Z, Sudová R, Réblová M (2019) Extensive sampling and highthroughput sequencing reveal Posidoniomyces atricolor gen. et sp. nov. (Aigialaceae, Pleosporales) as the dominant root mycobiont of the dominant Mediterranean seagrass Posidonia oceanica. MycoKeys 55: 59-86. https://doi.org/10.3897/ mycokeys. 55.35682

\begin{abstract}
Seagrasses provide invaluable ecosystem services yet very little is known about their root mycobiont diversity and distribution. Here we focused on the dominant Mediterranean seagrass Posidonia oceanica and assessed its root mycobiome at 32 localities covering most of the ecoregions in the NW Mediterranean Sea using light and scanning electron microscopy and tag-encoded 454-pyrosequencing. Microscopy revealed that the recently discovered dark septate endophytic association specific for $P$. oceanica is present at all localities and pyrosequencing confirmed that the $P$. oceanica root mycobiome is dominated by a single undescribed pleosporalean fungus, hitherto unknown from other hosts and ecosystems. Its numerous slow-growing isolates were obtained from surface-sterilised root segments at one locality and after prolonged cultivation, several of them produced viable sterile mycelium. To infer their phylogenetic relationships we sequenced and analysed the large (LSU) and small (SSU) subunit nrDNA, the ITS nrDNA and the DNA-directed RNA polymerase II (RPB2). The fungus represents an independent marine biotrophic lineage in the Aigialaceae (Pleosporales) and is introduced here as Posidoniomyces atricolor gen. et sp. nov. Its closest relatives are typically plantassociated saprobes from marine, terrestrial and freshwater habitats in Southeast Asia and Central America. This study expands our knowledge and diversity of the Aigialaceae, adds a new symbiotic lifestyle to this family and provides a formal name for the dominant root mycobiont of the dominant Mediterranean seagrass.
\end{abstract}

Copyright Martin Vohnik et al. This is an open access article distributed under the terms of the Creative Commons Attribution License (CC BY 4.0), which permits unrestricted use, distribution, and reproduction in any medium, provided the original author and source are credited. 


\section{Keywords}

dark septate endophytes, Dothideomycetes, marine fungi, root endophytes, seagrasses

\section{Introduction}

Although the occurrence of marine saprobic and endophytic fungi on mangroves and salt marsh plants is well-documented (e.g. Jones 1963; Jones and Pang 2012; Kohlmeyer and Kohlmeyer 1971; Gessner and Kohlmeyer 1976; Kohlmeyer and Volkmann-Kohlmeyer 1991, 2001, 2002), the mycobiota of seagrasses is generally neglected and relatively litthe understood (e.g. Kohlmeyer 1963; Kohlmeyer and Kohlmeyer 1979; Cuomo et al. 1985; Alva et al. 2002; Gnavi et al. 2014). Seagrasses are perennial flowering plants represented by several genera inhabiting shore environments practically everywhere outside the Arctic and Antarctic, but mainly in temperate, subtropical and especially tropical littoral zones. All seagrass genera are accommodated in various families of a single order, the Alismatales (Monocotyledons). Unlike most terrestrial and many aquatic plants, seagrasses seem to be devoid of mycorrhizae (Nielsen et al. 1999) and a specific root-fungus association has been so far reported only for a single seagrass species (Vohník et al. 2015).

Posidonia (Posidoniaceae) is the evolutionary oldest seagrass genus with the earliest fossil record from the Cretaceous (den Hartog 1970). It has a uniquely discontinuous distribution with eight of its nine species occurring in the Southern Hemisphere along the coast of Australia (Green and Short 2003). In our study, we focused on root mycobionts of the only non-Australian species, i.e. the dominant and endemic Mediterranean seagrass Posidonia oceanica. In the Mediterranean Sea, P. oceanica forms extensive clonal meadows which can be hundreds to thousands of years old and spread over one to several (up to 15) kilometres (Arnaud-Haond et al. 2012). These vast meadows are the primary source of carbon for the coastal ecosystems and, additionally, they play an important role in defining the coastal line and supply biogenic detritus made of seagrass roots, rhizomes and leaf debris entangling other living organisms like molluscs, algae or foraminifera (De Falco et al. 2017). Unlike other seagrasses, $P$. oceanica typically forms extensive branched root systems (Figure 1a) which support formation of "matte" (Figure 1b, c), i.e. a peat-like seabed layer which is exceptionally resistant to microbiological decay and may be up to several metres thick (Hemminga and Duarte 2000; Serrano et al. 2012).

The mycobiota of $P$. oceanica only recently gained appropriate attention; from the few available reports it seems to be predominated by fungi belonging to three classes and five orders of Ascomycota, i.e. Dothideomycetes (Pleosporales, Capnodiales), Leotiomycetes (Helotiales) and Sordariomycetes (Lulworthiales, Microascales and Papulaspora incertae sedis). These include obligate marine lignicolous fungi, ubiquitous surface-dwelling saprobes and endophytic fungi colonising roots, rhizomes and leaves, thus forming tighter (symbiotic) relationships with the host plant. Typically, they were growing on living or decaying plant parts (Kohlmeyer 1963; Cuomo et al. 1985) or were isolated as sterile mycelia and identified only by DNA sequence analysis (Panno et al. 2013; Gnavi et al. 2014; Vohník et al. 2016, 2017). They either belong to well-studied genera (e.g. Corollospora, Halotthia, Lulworthia and Papulaspora) or represent new marine lineages. 

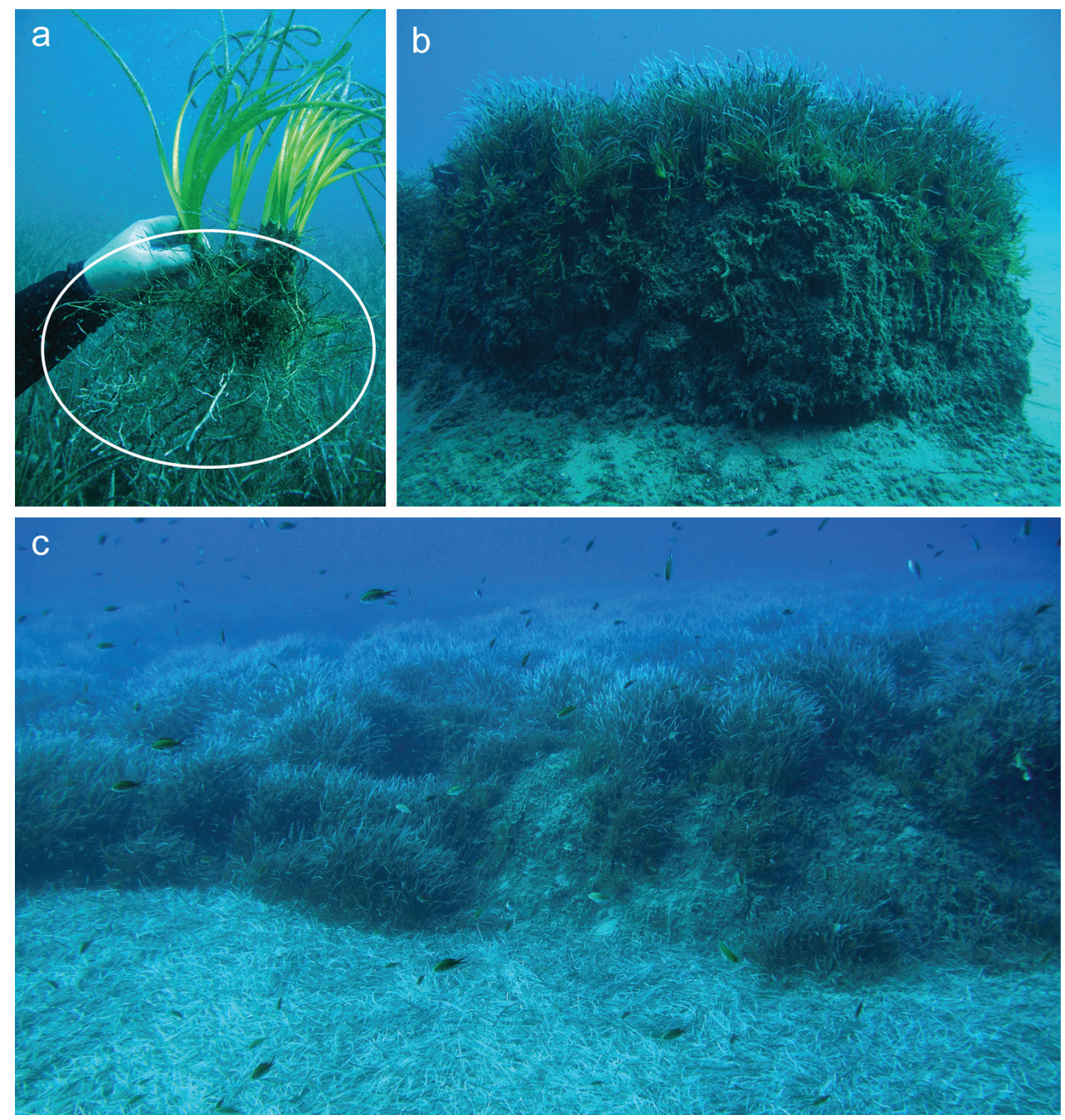

Figure I. The dominant Mediterranean seagrass Posidonia oceanica. a Overall appearance, note dense branched root system of the seagrass (encircled) b Posidonia oceanica growing on an approx. $1.5 \mathrm{~m}$ thick layer of matte $\mathbf{c}$ typical habitat of the dominant Mediterranean seagrass, note the layer of shed seagrass leaves on the seabed.

Our previous microscopic observations revealed that living terminal roots of $P$. oceanica, particularly their surface and the thick-walled hypodermis, are regularly colonised by an unknown fungus with dark septate hyphae (Vohník et al. 2015). The resulting association resembles colonisation by the so-called dark septate endophytes (DSE) which regularly occur in the roots of most terrestrial plants (e.g. Jumpponen and Trappe 1998; Vohník and Albrechtová 2011; Lukešová et al. 2015) but seemed to be absent in the marine environment. The association is characterised by the formation of sparse, dark pigmented hyphae, dense finger-like pseudoparenchymatous nets 
or loose hyphal sheaths on the root surface and melanised intracellular microsclerotia in the hypodermis. However, in contrast to typical terrestrial DSE, although the dark septate hyphae were also infrequently observed inside rhizodermal cells, they never colonised vascular tissues of the host roots. Interestingly, this association was absent in the roots of Cymodocea nodosa, a widely distributed seagrass in the Mediterranean Sea which sometimes accompanies P. oceanica (Vohník et al. 2015).

In our previous work focused on the diversity and distribution of $P$. oceanica root mycobionts, cultivations and 454-pyrosequencing of fungal DNA from surfacesterilised root segments from a few localities in the NW Mediterranean Sea revealed a relatively narrow fungal community lacking typical terrestrial and freshwater endophytes and mycorrhizal fungi (Vohník et al. 2016, 2017). This unusually limited fungal spectrum (cf. Kohout et al. 2012, 2013; Bruzone et al. 2017) was dominated by a single dark-pigmented mycobiont tentatively named "Pleosporales sp. MV-2012" (Vohník et al. 2016). Interestingly, this symbiotic fungus has not been documented in any of the other studies on P. oceanica mycobiota (see above) and to our knowledge it is not known from any other hosts and environments. Its extremely slow growth and characteristic colony morphology enable unequivocal identification already during the isolation stage but spore formation has never been observed (Vohník et al. 2016). Consequently, despite the striking DSE root colonisation pattern in vivo (Vohník et al. 2015), the absence of sexual characters and the lack of formation of conidia and conidiophores in axenic culture, either on agar media (standard or containing salt water) or on surface-sterilised root segments placed on nutrient media, pose a difficulty in estimating precise phylogenetic relationships of this dominant $P$. oceanica root mycobiont. Nevertheless, its preliminary position in the Aigialaceae (Pleosporales, Dothideomycetes), based on sequences of the partial nuclear large subunit (nucLSU) $28 \mathrm{~S}$ rDNA gene, was discussed in Vohník et al. (2016).

The present study was motivated by the need to confirm the presence/dominance of the pleosporalean DSE fungus in the P. oceanica root mycobiota at a much larger scale than previously studied as well as the need for circumscription and precise phylogenetic placement of this mycobiont into the fungal system. Thus, we characterised $P$. oceanica root mycobionts using tag-encoded 454-pyrosequencing at 32 localities in the NW Mediterranean Sea (covering the distribution of P. oceanica from its westernmost localities to the boundary between the Western and Eastern Mediterranean basins). We also isolated and characterised $P$. oceanica root mycobionts at the locality where the specific DSE association has been observed for the first time (Vohník et al. 2015). Subsequently, characteristic strains of the Pleosporales sp. MV-2012 were selected for its circumscription based on morphological characters and an analysis of a molecular data set consisting of sequences of the following nuclear markers: nucLSU, nuclear small subunit (nucSSU) 18S rDNA gene and the second largest subunit of the RNA polymerase II (RPB2) gene. Additionally, an analysis of the unusually divergent ITS region of nuclear rDNA was performed to screen the possible geographical variability of the dominant $P$. oceanica root mycobiont. 


\section{Materials and methods}

\section{Sampling}

Posidonia oceanica root samples were collected at 32 localities in seven states in the NW Mediterranean (Figure 2) representing four out of the eight Mediterranean Sea ecoregions (Table 1; see Notarbartalo di Sciara and Agardy 2010 in Giacoumi et al. 2013) at various depths using snorkelling and scuba diving. The samples for tag-encoded 454-pyrosequencing were collected in June, July and September 2012 whereas the samples for mycobiont isolation were collected in September 2016 (Table 1). Each locality was represented by a pooled sample consisting of five subsamples taken at least 3 meters apart (see Vohník et al. 2016).

\section{Characterisation of $P$. oceanica root mycobionts by 454-pyrosequencing}

For 454-pyrosequencing, root samples of the same weight representing individual localities were pooled into six sample sets (Figure 2, Table 1). DNA extraction, PCR amplification and sequencing was conducted as in Vohník et al. (2017). Briefly, after DNA extraction from surface-sterilised P. oceanica fine roots conducted using DNeasy Plant Mini Kit (Qiagen), the ITS region of the nrDNA was amplified in a two-step PCR with primers ITS1F/ITS4 (White et al. 1990; Gardes and Bruns 1993) in the first step. One negative control was included in the PCR analyses. From each DNA extract, two independent PCR reactions were run to avoid PCR bias. The obtained PCR products were then pooled, purified and used as a template for the second PCR with tagged ITS1/ITS4 primers. The resulting six samples and one negative control were purified, quantified, equimolarly mixed with other samples from the same 454-pyrosequencing plate and sequenced on the GS Junior platform (Roche).

In total, pyrosequencing yielded 32127 raw sequences which were subsequently processed in the pipeline SEED 2.0.4 (V̌̌trovský and Baldrian 2013). Quality check (min. quality score 25) and denoising yielded 30935 sequences. Sequences shorter than $500 \mathrm{bp}$ were excluded and the data set was trimmed to the $500 \mathrm{bp}$ sequence length. The obtained 15951 sequences were then clustered to molecular OTUs (MOTUs) using UPARSE implementation in USEARCH 8.1.1861 (Edgar 2013) with $97 \%$ similarity threshold. Chimeric sequences identified in this step (198) were deleted to prevent diversity overestimation. Also 81 global singletons were removed from the data set. The consensus sequences were constructed for each MOTU using MAFFT v.7.222 alignments (Katoh et al. 2009), based on the most abundant nucleotide at each position. These consensus sequences were then checked for their closest hits by BLAST algorithm using UNITE (Kóljalg et al. 2013) and GenBank (Sayers et al. 2019) as reference databases. Main MOTUs obtained in this study are listed in Table 2. 


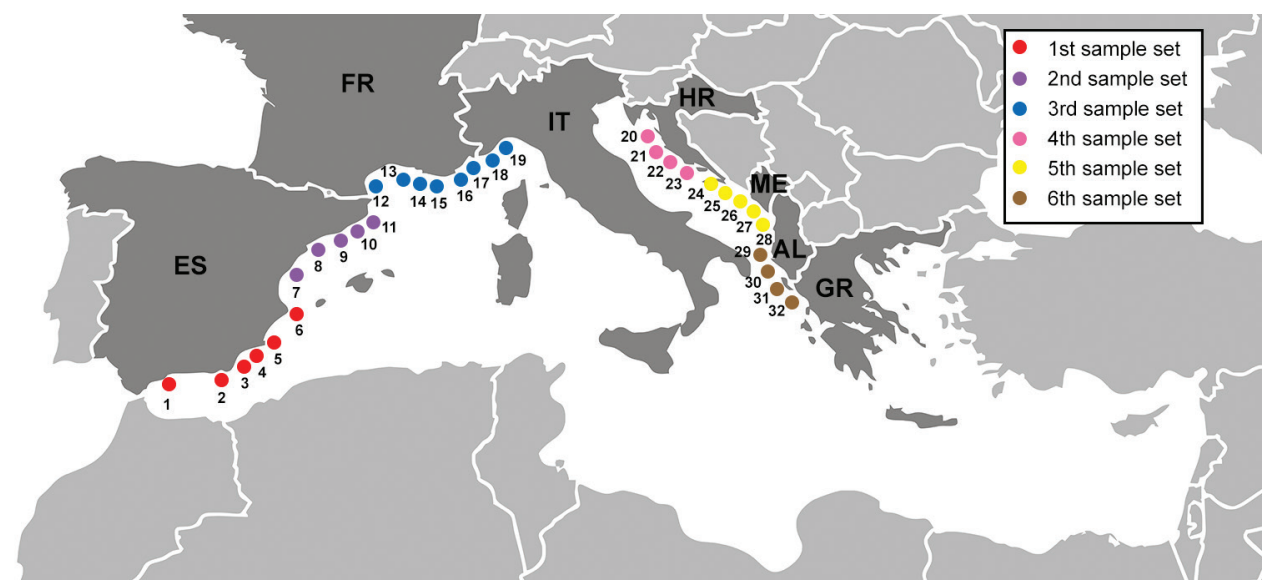

Figure 2. Map of the Mediterranean Sea with location of our 32 sampling sites. For further details see Table 1.

\section{Isolation and characterisation of $P$. oceanica root mycobionts at the original locality}

Root mycobionts were isolated from surface-sterilised terminal fine roots as described in Vohník et al. (2016) except that ten different media, amended with Novobiocin sodium salt (50 mg/L; Sigma-Aldrich, Germany) to prevent growth of bacteria, were used. These included glucose peptone yeast agar (GPYA; glucose $40 \mathrm{~g}$, peptone $5 \mathrm{~g}$, yeast extract $5 \mathrm{~g}$ and agar $15 \mathrm{~g}$ dissolved in $1 \mathrm{~L}$ of deionized water), GPYA + Posidonia extract, malt extract (MEA; HiMedia Pvt. Ltd., India), MEA + Posidonia extract, MEA with mycological peptone (MEAP; HiMedia), MEAP + Posidonia extract, modified Melin-Norkrans medium (MMN; Marx 1969), MMN + Posidonia extract, potato dextrose agar (PDA; HiMedia) and PDA + Posidonia extract. The Posidonia extract was prepared by soaking $200 \mathrm{~g}$ of $P$. oceanica leaves, roots, rhizomes and matte at $60{ }^{\circ} \mathrm{C}$ in $1 \mathrm{~L}$ of seawater for $30 \mathrm{~min}$ (Panno et al. 2013), filtrated and $100 \mathrm{~mL}$ of the filtrate was mixed with $900 \mathrm{~mL}$ of the respective media.

Segments of the surface-sterilised terminal fine roots (ca. 3-5 mm long) were incubated on the surface of the abovementioned solidified media at room temperature in the dark and periodically checked for mycelial growth. There were 50 segments per each medium in two square 25-compartment plastic Petri dishes, i.e. 500 segments in total. The incubation was terminated after ca. 10 months $\left(28^{\text {th }}\right.$ September $2016-3^{\text {rd }}$ July 2017) and the obtained isolates were conservatively grouped into several morphotypes using stereomicroscopy and colony characteristics according to Vohník et al. (2016).

\section{DNA extraction, amplification and Sanger sequencing}

DNA was extracted from multiple isolates of each morphotype/medium combination using Extract-N-Amp Plant Kits (Sigma-Aldrich, Germany) following manufacturer's instructions. Primers used for the amplification of genes and gene regions included: 1) 
Table I. List of the Posidonia oceanica localities sampled in this study.

\begin{tabular}{|c|c|c|c|c|c|c|}
\hline $\begin{array}{c}\text { Sample } \\
\text { set }^{1}\end{array}$ & $\begin{array}{c}\text { Locality } \\
\#^{2}\end{array}$ & $\begin{array}{c}\text { Locality } \\
\text { code }^{3}\end{array}$ & Locality name & \begin{tabular}{|l} 
Locality \\
ecoregion $^{4}$
\end{tabular} & GPS coordinates & $\begin{array}{c}\text { Sampling } \\
\text { time }\end{array}$ \\
\hline \multirow[t]{6}{*}{$1^{\text {st }}$} & 1 & ES-21 & Bahía de la Plata, Estepona & $\begin{array}{l}\text { Alboran } \\
\text { Sea }\end{array}$ & $36.42749 \mathrm{~N}, 5.12923 \mathrm{~W}$ & VII/2012 \\
\hline & 2 & ES-22 & Cabo de Gata & dtto & $36.72595 \mathrm{~N}, 2.19537 \mathrm{~W}$ & VII/2012 \\
\hline & 3 & ES-23 & Villaricos & $\begin{array}{c}\text { Algero- } \\
\text { Provencal } \\
\text { Basin }\end{array}$ & $37.26676 \mathrm{~N}, 1.75151 \mathrm{~W}$ & $\mathrm{VII} / 2012$ \\
\hline & 4 & ES-27 & Cope, Calabardina & dtto & $37.43672 \mathrm{~N}, 1.48422 \mathrm{~W}$ & $\mathrm{VII} / 2012$ \\
\hline & 5 & ES-24 & Cabo de Palos & dtto & $37.63355 \mathrm{~N}, 0.68996 \mathrm{~W}$ & $\mathrm{VII} / 2012$ \\
\hline & 6 & ES-25 & Calp, Cala el Racó & dtto & $38.63556 \mathrm{~N}, 0.07124 \mathrm{E}$ & $\mathrm{VII} / 2012$ \\
\hline \multirow[t]{6}{*}{$2^{\text {nd }}$} & 7 & ES-28 & Platja de Capicorb, Torreblanca & dtto & $40.20711 \mathrm{~N}, 0.25956 \mathrm{E}$ & $\mathrm{VII} / 2012$ \\
\hline & 8 & ES-26 & $\begin{array}{l}\text { Platja dels Muntanyans, } \\
\text { Torredembarra }\end{array}$ & dtto & $41.14475 \mathrm{~N}, 1.41552 \mathrm{E}$ & $\mathrm{VII} / 2012$ \\
\hline & 9 & ES-11 & $\begin{array}{c}\text { Platja de Llafranc, Callela de } \\
\text { Palafrugell }\end{array}$ & dtto & $41.89343 \mathrm{~N}, 3.19391 \mathrm{E}$ & $\mathrm{VI} / 2012$ \\
\hline & 10 & ES-10 & Platja de Tamariu & dtto & $41.91756 \mathrm{~N}, 3.20761 \mathrm{E}$ & $\mathrm{VI} / 2012$ \\
\hline & 11 & ES-9 & Cala Montgó, L'Escala & dtto & $42.10744 \mathrm{~N}, 3.16892 \mathrm{E}$ & $\mathrm{VI} / 2012$ \\
\hline & 12 & FR-8 & Anse de Paulilles, Paulilles & dtto & $42.50236 \mathrm{~N}, 3.12456 \mathrm{E}$ & $\mathrm{VII} / 2012$ \\
\hline \multirow[t]{7}{*}{$3^{\text {rd }}$} & 13 & FR-20 & Les Arnettes & dtto & $43.32922 \mathrm{~N}, 5.03849 \mathrm{E}$ & $\mathrm{VI} / 2012$ \\
\hline & 14 & FR-7 & Baie de Cousse, Sanary-sur-Mer & dtto & $43.12054 \mathrm{~N}, 5.77545 \mathrm{E}$ & $\mathrm{VI} / 2012$ \\
\hline & 15 & FR-19 & Cabasson & dtto & $43.09926 \mathrm{~N}, 6.32504 \mathrm{E}$ & $\mathrm{VI} / 2012$ \\
\hline & 16 & FR-6 & Cap Roux, Saint-Raphaël & dtto & $43.45026 \mathrm{~N}, 6.91951 \mathrm{E}$ & $\mathrm{VI} / 2012$ \\
\hline & 17 & FR-5 & Antibes & dtto & $43.55726 \mathrm{~N}, 7.12209 \mathrm{E}$ & $\mathrm{VI} / 2012$ \\
\hline & 18 & IT-4 & Finale Ligure & dtto & $44.17337 \mathrm{~N}, 8.36765 \mathrm{E}$ & $\mathrm{VI} / 2012$ \\
\hline & 19 & IT-3 & Mulinetto Beach, Cogoleto & dtto & $44.38016 \mathrm{~N}, 8.63467 \mathrm{E}$ & $\mathrm{VI} / 2012$ \\
\hline \multirow[t]{4}{*}{$4^{\text {th }}$} & 20 & HR-37 & Neviđane & $\begin{array}{l}\text { Adriatic } \\
\text { Sea }\end{array}$ & $43.98368 \mathrm{~N}, 15.33831 \mathrm{E}$ & $\mathrm{IX} / 2012$ \\
\hline & 21 & HR-38 & Dobropoljana & dtto & $43.98713 \mathrm{~N}, 15.33295 \mathrm{E}$ & IX/2012 \\
\hline & 22 & HR-39 & Žman & dtto & $44.00308 \mathrm{~N}, 15.05930 \mathrm{E}$ & IX/2012 \\
\hline & 23 & HR-2 & Kukuljar & dtto & $43.75960 \mathrm{~N}, 15.63410 \mathrm{E}$ & IX/2012 \\
\hline \multirow[t]{5}{*}{$5^{\text {th }}$} & 24 & HR-1 & Borak & dtto & $42.92236 \mathrm{~N}, 17.34685 \mathrm{E}$ & $\begin{array}{l}\text { IX/2012 \& } \\
\text { IX/2016 }\end{array}$ \\
\hline & 25 & ME-36 & Krimovica & dtto & $42.27985 \mathrm{~N}, 18.78738 \mathrm{E}$ & IX/2012 \\
\hline & 26 & ME-35 & Sveti Stefan I & dtto & $42.25022 \mathrm{~N}, 18.89463 \mathrm{E}$ & IX/2012 \\
\hline & 27 & ME-34 & Petrovac & dtto & $42.19762 \mathrm{~N}, 18.93726 \mathrm{E}$ & IX/2012 \\
\hline & 28 & ME-33 & Crni Rt, Sutomore & dtto & $42.13595 \mathrm{~N}, 19.01549 \mathrm{E}$ & IX/2012 \\
\hline \multirow[t]{4}{*}{$6^{\text {th }}$} & 29 & AL-31 & Orikum I & dtto & $40.34226 \mathrm{~N}, 19.40898 \mathrm{E}$ & IX/2012 \\
\hline & 30 & AL-32 & Orikum II & dtto & $40.35723 \mathrm{~N}, 19.40926 \mathrm{E}$ & IX/2012 \\
\hline & 31 & GR-30 & Kalamionas Beach, Kassiopi & Ionian Sea & $39.78941 \mathrm{~N}, 19.91542 \mathrm{E}$ & IX/2012 \\
\hline & 32 & GR-29 & Kalami & dtto & $39.74227 \mathrm{~N}, 19.93443 \mathrm{E}$ & IX/2012 \\
\hline
\end{tabular}

${ }^{1}$ grouping for pyrosequencing, see Materials and Methods

${ }^{2}$ sequential numbering corresponding to Figure 2 (along the coast from west to east)

${ }^{3}$ continues from Vohník et al. 2015, 2016 and 2017. AL = Albania, ES = Spain, FR = France, GR = Greece, HR= Croatia, IT = Italy, ME = Montenegro

${ }^{4}$ according to Notarbartalo di Sciara and Agardy (2010) in Giacoumi et al. (2013)

NS7, ITS1F, ITS2 and ITS4 (White et al. 1990; Gardes and Bruns 1993) for the ITS nrDNA, 2) LR0R and LR5 (Vilgalys and Hester 1990; Vilgalys unpublished: www. botany.duke.edu /fungi/mycolab) for the partial nucLSU (D1 and D2 domains), 3) NSSU131 and NS24 (Gargas and Taylor 1992; Kauff and Lutzoni 2002) for the whole 


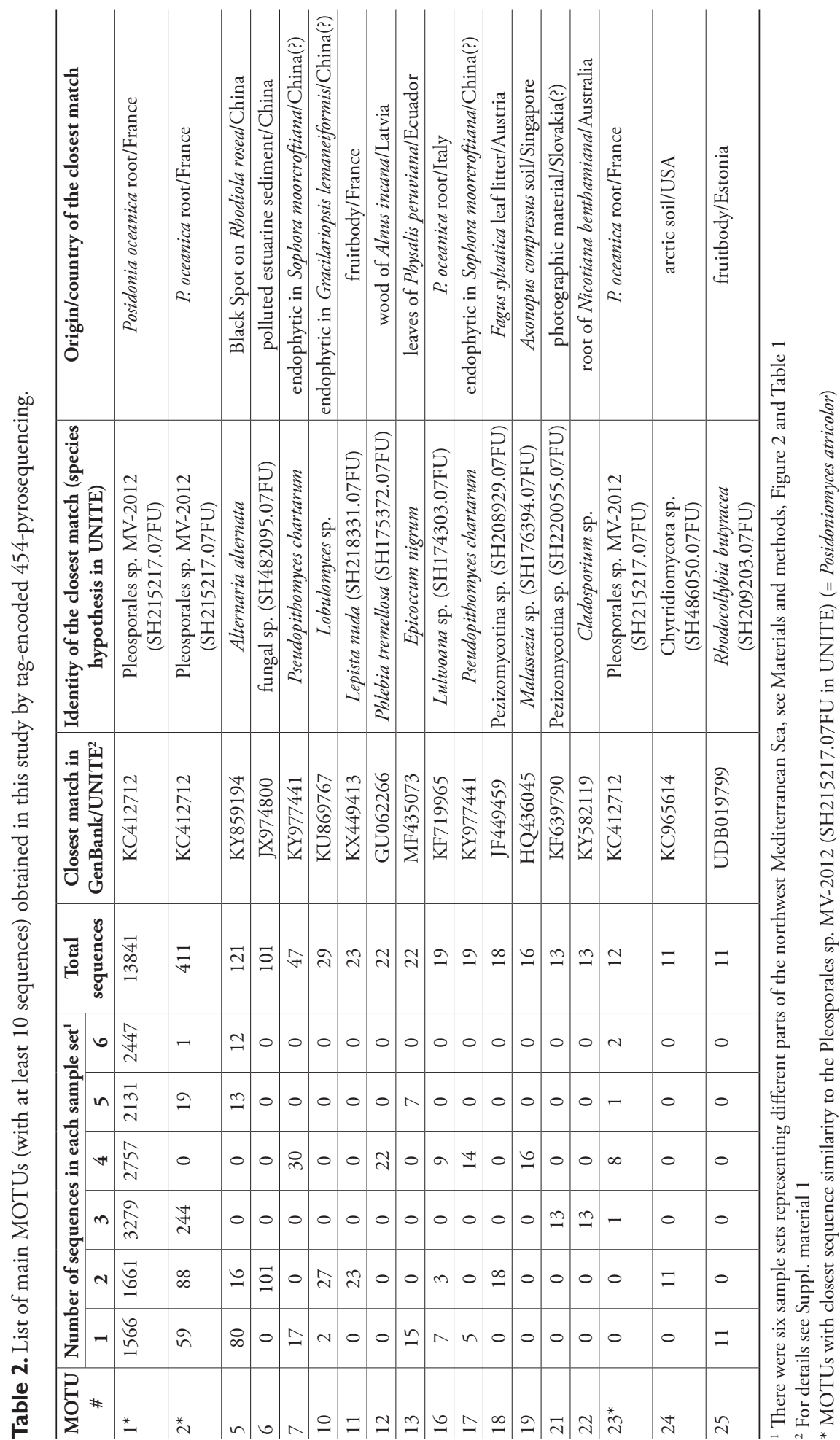


nucSSU and 4) fRPB2-5F and fRPB2-7cR (Liu et al. 1999) for the segments 5-7 of the RPB2. PCR amplifications were carried out according to the methods described in Vohník et al. (2012). Primers used to sequence the purified PCR products included the amplification primers and nested primers: 1) NSSU897R, NSSU1088 and NS6 (White et al. 1990; Kauff and Lutzoni 2002) for the nucSSU and 2) RPB2-980F and RPB2$1014 \mathrm{R}$ (Reeb et al. 2004) for segments 5-7 of the RPB2 gene. Automated sequencing was carried out by Macrogen Europe Laboratory (Macrogen Inc., The Netherlands).

The obtained sequences were screened in Finch TV v.1.4.0 (https://digitalworldbiology.com/FinchTV) for possible machine errors, manually edited when needed and subjected to BLAST searches (BLASTn) in GenBank (Altschul et al. 1997). Sequences similar to identical to those previously deposited in GenBank as "Pleosporales sp. MV2012" (Vohník et al. 2016, 2017) were aligned using ClustalW implemented in BioEdit v.7.1.8 (Hall 1999) to further screen their heterogeneity.

\section{Sequence alignment and phylogenetic analyses}

GenBank accession numbers for ITS, nucLSU, nucSSU and RPB2 sequences generated in this study and previously published sequences of the Aigialaceae (Pleosporales, Dothideomycetes) are listed in Suppl. material 2. Homologous nucLSU, nucSSU and $R P B 2$ sequences of members of the Aigialaceae were selected from the top-scoring matches using BLASTn and retrieved from GenBank.

The nucLSU, nucSSU and RPB2 sequences were manually aligned in BioEdit. The $\mathrm{RPB} 2$ sequences were transformed into protein sequences maintaining a correct reading frame using the BioEdit programme. This alignment was improved by taking into account the exchangeability of amino acids with similar chemical properties at certain positions. The protein alignment was converted back into a DNA alignment. Single locus data sets for Aigialaceae (nucLSU: 46 sequences/876 characters including gaps; nucSSU: 40/1044; RPB2: 24/940) were assessed for conflicts using the 70\% reciprocal bootstrap criterion (Mason-Gamer and Kellogg 1996) based on the comparison of the trees obtained with 1000 bootstrap (BS) replicates with RAxML-HPC v.7.0.3 (Stamatakis 2006). Conflict-free datasets were concatenated into a multi-locus alignment (deposited as TreeBASE 24210) that was subjected to a phylogenetic analysis.

Phylogenetic relationships of the Pleosporales sp. MV-2012 were inferred based on the analysis of the combined nucLSU-nucSSU-RPB2 sequences of 42 representatives of the Aigialaceae. Four Botryosphaeriales (Lasiodiplodia lignicola, Neofusicoccum ribis, Phyllosticta ampelicida and Saccharata kirstenboschensis) were used as an outgroup to root the tree. The first 49, 103 and 123 nt of nucLSU, nucSSU and RPB2 at the 5'-end and 480 and 595 nt of nucLSU and nucSSU at the 3'-end, respectively, were excluded from the alignment because of the incompleteness of the majority of sequences. Ambiguous regions were excluded from the alignment. To examine intraspecific variability, a phylogenetic analysis of 17 ITS sequences of the Pleosporales sp. MV-2012 strains and four other members of the Aigialaceae was conducted, with Astrosphaeriella bambusae (Pleosporales) selected 
as an outgroup to root the tree. Due to a long insertion in the ITS1 in all isolates of the Pleosporales sp. MV-2012, a larger part of this sequence was not homologous with the rest of ITS1 sequences of the Aigialaceae. Therefore, the first $334 \mathrm{nt}$ at the 3'-end of ITS1 were excluded and only the remaining $115 \mathrm{nt}$ of ITS1, whole 5.8S and ITS2 were analysed.

The combined dataset was partitioned into three subsets of nucleotide sites (nucLSU, nucSSU, RPB2) for which we assumed rate heterogeneity. Maximum Likelihood (ML) and Bayesian Inference (BI) analyses were used to estimate phylogenetic relationships. ML analyses were performed with RAxML-HPC v.7.0.3 with a GTRCAT approximation. Nodal support was determined by non-parametric BS analysis with 1000 replicates. $\mathrm{BI}$ analyses were performed in a likelihood framework as implemented in MrBayes v.3.2.6 (Huelsenbeck and Ronquist 2001) through the CIPRES Science Gateway v.3.3 (http:// www.phylo.org) (Miller et al. 2010). For the BI approach, MrModeltest2 v.2.3 (Nylander 2008) was used to infer the appropriate substitution model that best fit the model of DNA evolution. The SYM+G model was selected according to the Akaike information criterion for ITS and all partitions of the Aigialaceae data sets. Two Bayesian searches were performed using default parameters. The B-MCMCMC analyses lasted until the average standard deviation of split frequencies was below 0.01 with trees saved every 1000 generations. The first $25 \%$ of saved trees, representing the burn-in phase of the analysis, were discarded. The remaining trees were used for calculating posterior probabilities (PP) of recovered branches. The illustration of phylogenetic relationships is a ML tree.

\section{Results}

\section{Characterisation of $P$. oceanica root mycobionts by 454-pyrosequencing}

The obtained sequences clustered into 61 MOTUs. Read numbers of 13 MOTUs detected in the negative control were subtracted from the read numbers of these particular MOTUs in each of the six samples (if present there), resulting in 14917 sequences in total remaining in the dataset. The most frequent MOTU 1 (13841 sequences in total) was present in all six sample sets (min. 1566, max. 3279 and avg. 2307 sequences per set) and matched with $99.8 \%$ similarity and $95.2 \%$ coverage with the sequence KC412712 (see Table 2) derived from the Pleosporales sp. MV-2012 (UNITE species hypothesis SH215217.07FU) isolate P15 previously obtained from P. oceanica surface-sterilized root segment collected at one of the localities also investigated in this study (France, Baie de Cousse, Sanary-sur-Mer; Table 1) (Vohník et al. 2016). Twenty one other MOTUs, including the second most frequent MOTU 2 (411 sequences in total) present in five sample sets (min. 1, max. 244 and avg. 69 sequences per set) matched with sequences representing the same species hypothesis SH215217.07FU (Suppl. material 1). When counting all these 22 MOTUs together, they comprised 14334 sequences, i.e. $96 \%$ of all sequences. In contrast, the two MOTUs (MOTU 16 and MOTU 48) with a close match to mycobionts from the family Lulworthiaceae were represented only by 19 and four sequences and found only in three and two sample sets, respectively (Table 2, Suppl. material 1). The third most frequent MOTU 
5 represented the ubiquitous ascomycete Alternaria alternata and the sequences of the fourth most frequent MOTU 6 matched with an undescribed fungus (UNITE species hypothesis SH482095.07FU) from Chinese polluted estuarine sediment. All other MOTUs had each less than 100 sequences in total and represented various Ascomycota, Basidiomycota and Chytridiomycota from mostly terrestrial habitats (many as plant endophytes) of worldwide distribution (see Table 2, Suppl. material 1).

\section{Isolation and characterisation of $P$. oceanica root mycobionts at the original locality}

In total, we obtained 130 fungal mycelial isolates, i.e. $26 \%$ of the original 500 surfacesterilised root segments yielded mycelial isolates. There were no obvious effects of the isolation media on the mycelial isolate recovery except that the most isolates (i.e. 26) were obtained on PDA + Posidonia extract followed by PDA (23 isolates). With respect to recovery of the Pleosporales sp. MV-2012, the most efficient media were MMN and PDA + Posidonia extract with 55.6\% and 53.8\%, respectively. MMN and PDA were the two isolation media used in the first study to report the Pleosporales sp. MV-2012 from P. oceanica roots (Vohník et al. 2016).

Most of the obtained isolates were conservatively grouped into two dominant morphotypes, i.e. "Black" (62 isolates) and "Yellow" (38), where the former was morphologically identical to the Pleosporales sp. MV-2012 and the latter roughly corresponded to the Lulworthiales sp. MV-2012 described in Vohník et al. (2016, 2017). Approximately one third of the Black isolates, all the Yellow isolates and all remaining isolates were subjected to DNA extraction, amplification and sequencing which led to identification of 91 isolates. Since all sequenced Black isolates yielded high-quality sequences matching the Pleosporales sp. MV-2012, it was likely that also the rest of the Black isolates (i.e. those that were not selected for sequencing) belonged to this species, i.e. in total 112 isolates (ca. $86 \%$ ) were identified. Out of the identified isolates, the Pleosporales sp. MV-2012 represented 54.5\%. All the Yellow isolates belonged to the Lulworthiales and matched the Lulworthiales sp. MV-2012, the Lulworthiales sp. MV-2012B (see Vohník et al. 2017) and Lulwoana sp. The remaining unidentified isolates either failed to amplify or produced mixed sequences suggesting their non-axenic status (data not shown).

After prolonged cultivation, several Pleosporales sp. MV-2012 isolates started to produce submerged mycelium and two of them were successfully transferred and maintained on potato carrot agar (PCA). These isolates were used for the phylogenetic analysis and the formal description of the dominant $P$. oceanica root mycobiont (see below).

\section{Phylogenetic analysis}

A previous phylogenetic analysis of nucLSU sequences of members of nine families of the Pleosporales (Vohník et al. 2016) positioned the Pleosporales sp. MV-2012 in the Aigialaceae. In line with these results, we performed a subsequent analysis and phylogenetic relationships were inferred based on the combined nucLSU-nucSSU-RPB2 sequences of 


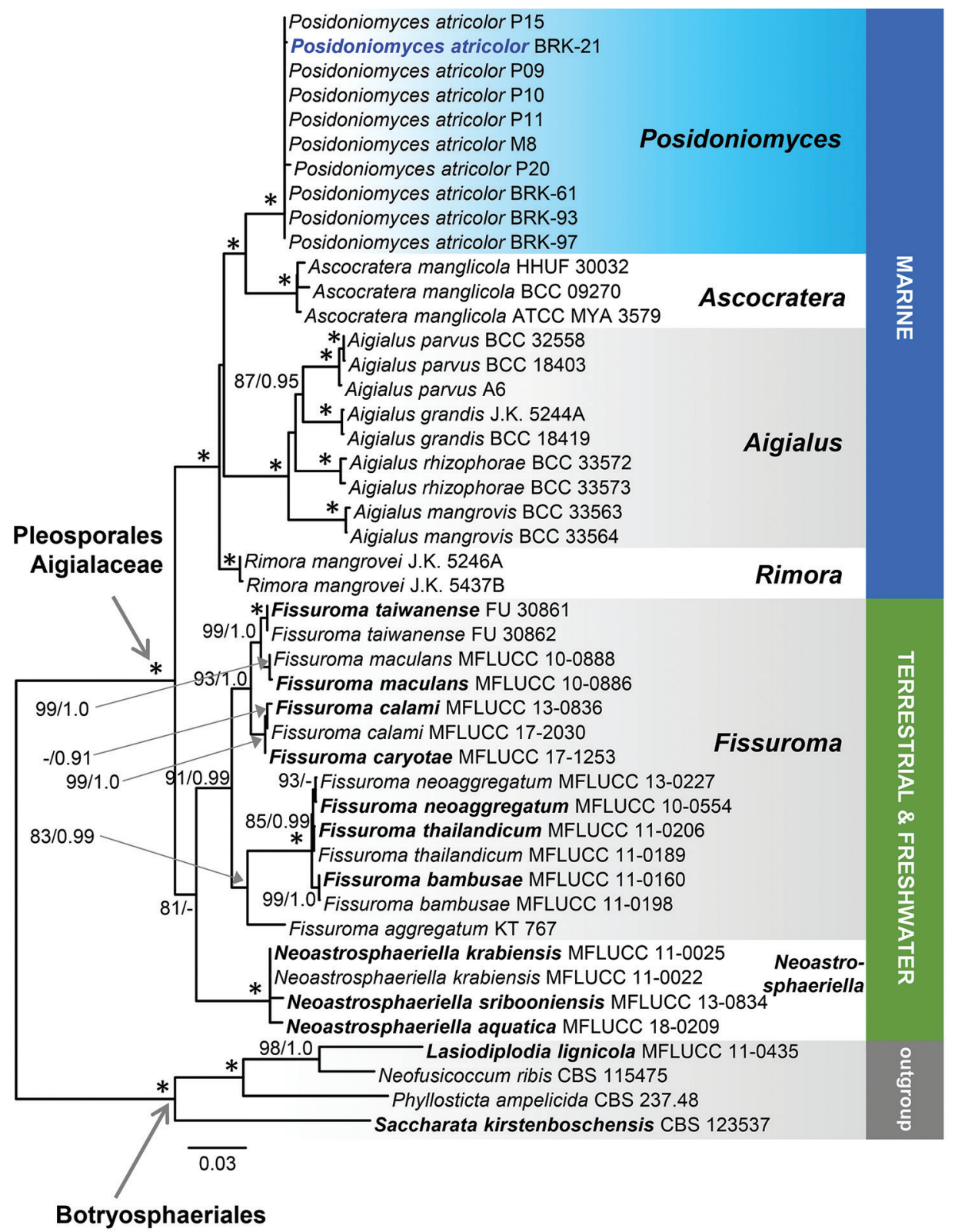

Figure 3. Phylogram generated from maximum likelihood analysis based on combined nucLSU, nucSSU and RPB2 sequence data for Posidoniomyces atricolor and the Aigialaceae. Species names given in bold are type species. The ex-type of the taxonomic novelty is in bold and blue. An asterisk $\left(^{*}\right)$ indicates branches with ML BS $=100 \%$ and PP values $=1.0$. Branch support of nodes $\geq 70 \% \mathrm{ML}$ BS and $\geq 0.90$ $\mathrm{PP}$ is indicated above or below branches.

10 isolates of the Pleosporales sp. MV-2012 and 32 additional isolates representing 17 species of five genera (Ascocratera, Aigialus, Rimora, Fissuroma and Neoastrosphaeriella) of the Aigialaceae. The full data set consisted of 2860 characters and 936 unique char- 

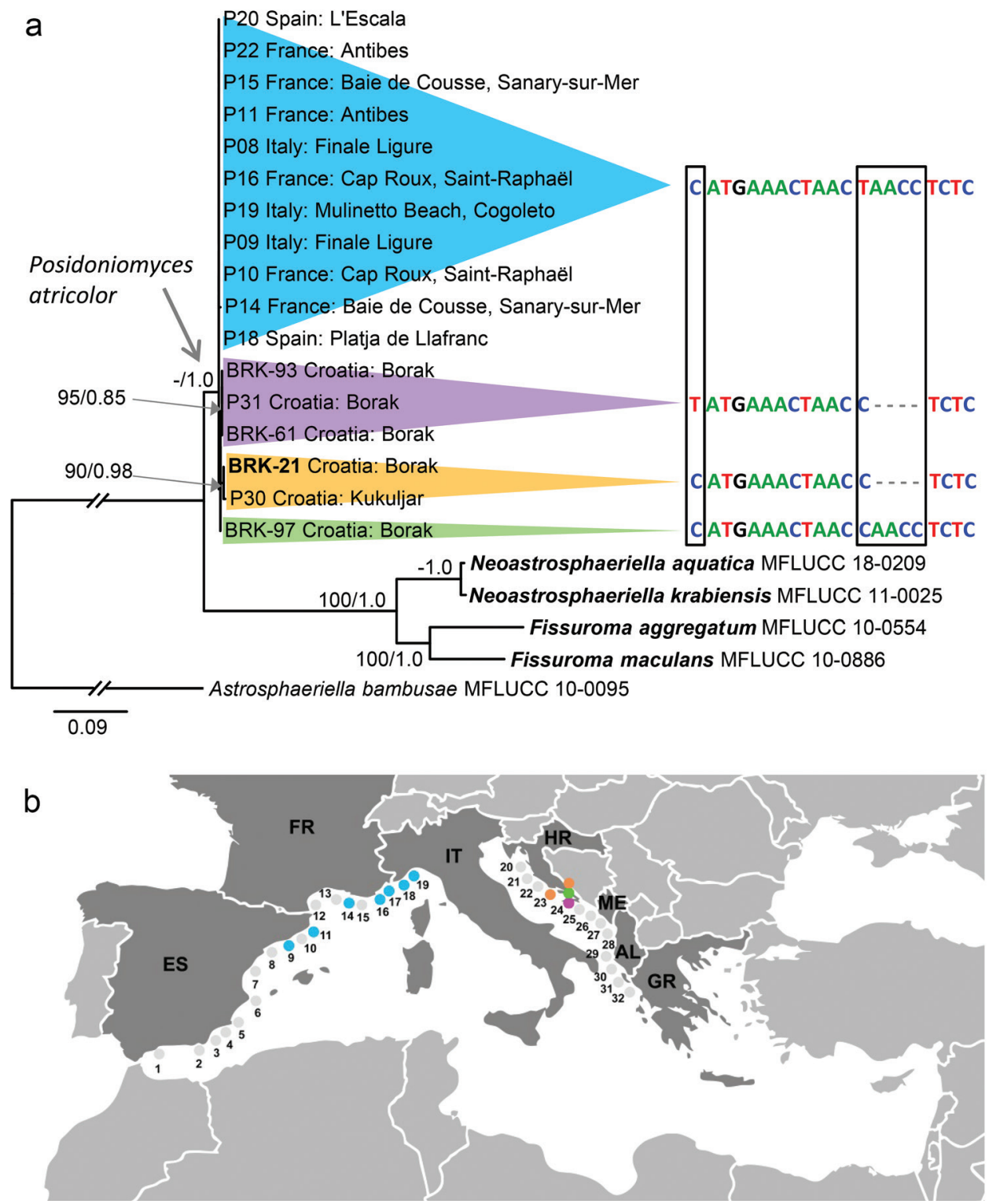

Figure 4. Phylogram and map showing a distribution pattern of Posidoniomyces atricolor. a Phylogram generated from maximum likelihood analysis based on ITS sequence data for Posidoniomyces atricolor and representatives of the Aigialaceae $\mathbf{b}$ map of the Mediterranean Sea with our 32 sampling sites. Sites in blue, orange, violet and green colour indicate locations of $P$. atricolor strains with corresponding mutations in ITS2 sequences.

acter sites. There were no differences in the topologies of trees generated from BI and ML analyses. In the ML tree (Figure 3), members of the Aigialaceae (100\% ML BS/1.0 PP) formed two subclades defined by ecology. One subclade (81/0.84) contained taxa known only from terrestrial and freshwater habitats, i.e. Fissuroma and Neoastrosphaeriella. The other subclade (100/1.0) contained marine saprobic species of Ascocratera, 
Aigialus and Rimora occurring on mangroves growing in estuarine environments and also a new marine lineage represented by the Pleosporales sp. MV-2012 associated with the roots of the seagrass $P$. oceanica and described as a new genus Posidoniomyces below.

The second analysis was based on ITS (partial ITS1, 5.8S and ITS2) sequences of 17 isolates of $P$. atricolor from nine localities in Croatia, France, Italy and Spain and additional four and only available ITS sequences of representatives of the Aigialaceae, Fissuroma and Neoastrosphaeriella. The data set consisted of 494 characters and 194 unique character sites. The topologies of trees from BI and ML analyses were identical. The ML tree is shown in Figure 4. Posidoniomyces forms monophyletic clade (49/1.0) with four subclades, which correspond to several indels in the ITS2. These changes in the primary sequence characterise populations of $P$. atricolor and their distribution pattern on the north-west coast of France and Spain and north-central part of the Adriatic coast of Croatia.

\section{Taxonomy}

\section{Posidoniomyces Vohník \& Réblová, gen. nov.} MycoBank MB 830266

Diagnosis. In vivo, colonisation pattern of host roots resembles colonisation by the socalled dark septate endophytes (DSE) ubiquitous in the roots of most terrestrial plants. However, the dark septate hyphae and microsclerotia of Posidoniomyces never colonise vascular tissues of the host roots and are mostly confined to the hypodermis.

Type species. Posidoniomyces atricolor Vohník \& Réblová

Etymology. Named after the host seagrass Posidonia oceanica and myces (Greek), meaning fungus.

Description. Root mycobiont of the dominant and endemic Mediterranean seagrass Posidonia oceanica. In vivo, hyphae brown, septate, forming intracellular microsclerotia in the hypodermis of the terminal fine roots and finger-like pseudoparenchymatous net on the surface of these roots, i.e. a colonisation pattern resembling the DSE association ubiquitous in the roots of terrestrial plants. In vitro, two distinct colonial morphotypes named compact and mycelial (often with aerial hyphae) are consistently formed. Colonies brown, mycelium composed of septate, hyaline, subhyaline to pigmented hyphae with intercalary, terminal, rarely lateral, one-celled globose, subglobose to ellipsoidal swellings that are prominent especially on the surface of the compact colonies. Sexual state unknown.

\section{Posidoniomyces atricolor Vohník \& Réblová, sp. nov. MycoBank MB 830267 \\ Figs 5, 6}

Typification. CROATIA. Dubrovnik-Neretva County: Potomje, Borak (42.92236N, 17.34685E), isolated from a surface-sterilised healthy-looking terminal root of Posidonia oceanica, 28 Sep 2016, M.Vohník \& O.Borovec BRK-21 (holotype: PRA-15294!, dried 
culture - compact morphotype from a surface-sterilised root segment; isotype: PRA15295!, dried culture - mycelial morphotype derived from the original compact colony).

Etymology. Atricolor (L), meaning black, dark coloured, referring to the dark pigmented hyphae.

Description in culture. Mycelial colonial morphotype: Colonies on PCA 6-8 mm in diameter in $3 \mathrm{mo}$, circular, convex, appearing woolly, margin entire, aerial mycelium abundant, densest at the centre, cobwebby towards the margin, white to grey with a pale brown zone at the margin, colony surface with a dark brown hue formed by substrate mycelium and released pigment; reverse brown. Compact colonial morphotype: Colonies on PCA 5-6 mm in diameter in $8 \mathrm{mo}$, irregular, pulvinate, deeply furrowed, appearing mucoid-waxy to faintly floccose, of a "cartilage" consistency, become hollow upon aging, margin lobate, aerial mycelium scant, hyaline to pale brown, colony surface dark brown; reverse dark brown. Compact colonies, which are formed in vitro on sterilised roots of $P$. oceanica, become irregular in shape, folded and furrowed in an almost cerebriform pattern, cacao brown, ca. 5-6 $\mathrm{mm}$ long on the longest side after several months of cultivation. Hyphae hyaline to pale brown, septate, smoothwalled and $2-3(-3.5) \mu \mathrm{m}$ wide, often with terminal, intercalary, rarely with lateral, one-celled, thick-walled globose, subglobose to ellipsoidal swellings 10-14 $\mu \mathrm{m}$ wide; hyphae frequently protrude from these swellings and continue growing. Surface of the compact colonies covered by hyaline to subhyaline, smooth-walled hyphae with terminal, capitate swellings. Chlamydospores, conidiogenous cells or conidia, ascomatal initials and ascomata not observed.

Description in vivo. In vivo hyphae pigmented, septate, smooth-walled and (2-)3$4(-5) \mu \mathrm{m}$ wide, colonising root cells of the host and/or forming an extraradical hyphal sheath, i.e. a finger-like pseudoparenchymatous net on the root surface. Microsclerotia intracellular, melanised, round or elongated and $8-10(-17) \mu \mathrm{m}$ wide, present in the $P$. oceanica root hypodermis. Intracellular hyphae also infrequently occur in the rhizodermis.

Specimens examined. Croatia. Dubrovnik-Neretva County: Potomje, Borak $(42.92236 \mathrm{~N}, 17.34685 \mathrm{E})$, isolated from surface-sterilised healthy-looking terminal roots of P. oceanica, 28 Sep 2016, M.Vohník \& O.Borovec BRK-11 (PRA-15296); ibid., BRK-25 (PRA-15298); BRK-34 (PRA-15297); BRK-60 (PRA-15300); BRK-61 (PRA-15293); BRK-76 (PRA-15302); BRK-87 (PRA-15299); BRK-93 (PRA-15301), BRK-97 (PRA-15303). Croatia. Split-Dalmatia County: Palagruža archipelago, Gangaro Island I (43.8639N, 15.4341E), isolated from a surface-sterilised healthy-looking terminal root of P. oceanica, 3 September 2012, M.Vohník \& O.Borovec M8. France. Provence-Alpes-Côte d'Azur Region: Var Department, Saint-Raphaël, Cap Roux $(43.45026 \mathrm{~N}, 6.91951 \mathrm{E})$, isolated from a surface-sterilised healthy-looking terminal root of P. oceanica, 17 June 2012, M.Vohník P10. France. Provence-Alpes-Côte d'Azur Region: Alpes-Maritimes Department, Antibes (43.55726N, 7.12209E), isolated from a surface-sterilised healthy-looking terminal root of $P$. oceanica, 18 June 2012, M.Vohník P11. France. Provence-Alpes-Côte d'Azur Region: Var Department, Sanarysur-Mer (43.12054N, 5.77545E), isolated from a surface-sterilised healthy-looking terminal root of P. oceanica, 19 June 2012, M.Vohník P15. Italy. Liguria Region: Savona Province, Gulf of Genoa, Finale Ligure (44.17337N, 8.36765E), isolated from a sur- 

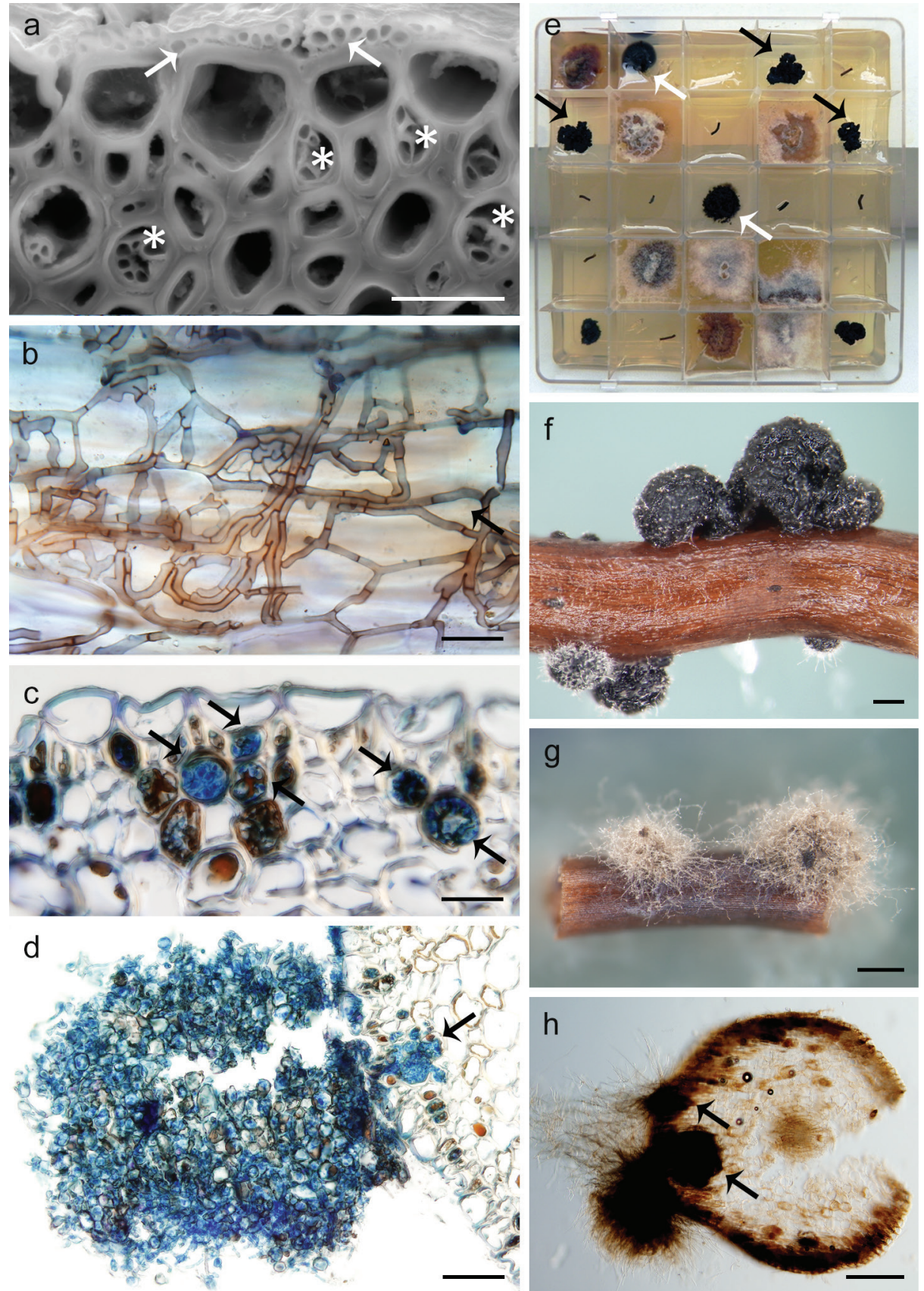

Figure 5. In vivo root colonisation pattern and in vitro cultural aspects of Posidoniomyces atricolor. a In vivo colonisation on the root surface (arrows) and in the hypodermis (asterisks) of P. oceanica b DSE colonisation on the root surface $\mathbf{c}$ germinating microsclerotia stained with trypan blue (arrows) $\mathbf{d}$ compact colony developed from microsclerotia (arrow) e surface-sterilised root segments yielding $P$. atricolor compact colonies (black arrows), sometimes with substrate mycelium (white arrows) $\mathbf{f}$ compact colonial morphotype $\mathbf{g}$ mycelial colonial morphotype $\mathbf{h}$ mycelial morphotype developing from microsclerotia (arrows) in transversal section. Scale bars: $20 \mu \mathrm{m}(\mathbf{a}, \mathbf{b}), 50 \mu \mathrm{m}(\mathbf{c}), 100 \mu \mathrm{m}(\mathbf{d}), 200 \mu \mathrm{m}(\mathbf{f}, \mathbf{h}), 500 \mu \mathrm{m}(\mathbf{g})$. 

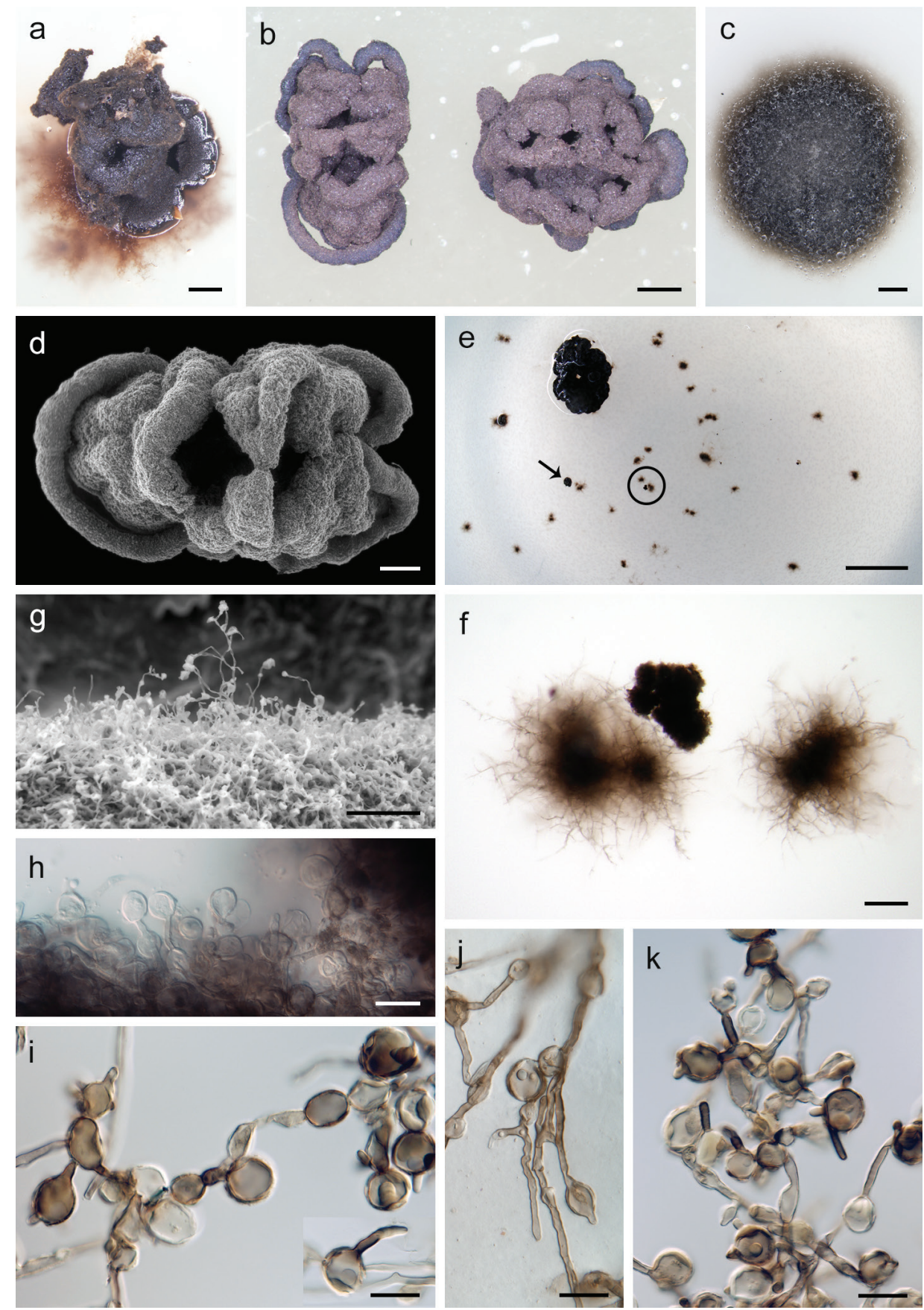

Figure 6. Colonial morphotypes of Posidoniomyces atricolor in vitro (type isolate BRK-21). a Compact morphotype with substrate mycelium $\mathbf{b}, \mathbf{d}$ compact colonies with a cerebriform pattern $\mathbf{c}$ colony of $P$. atricolor on PCA e rhizoidal and compact (arrow) daughter colonies on PCA washed with sterile tap water $\mathbf{f}$ detail of the colonies encircled in $\mathbf{e} ; \mathbf{g}, \mathbf{h}$ terminal capitate swellings on the surface of compact colonies i-k conspicuous swellings on aerial mycelium. Scale bars: $500 \mu \mathrm{m}(\mathbf{a}, \mathbf{d}), 1000 \mu \mathrm{m}(\mathbf{b}, \mathbf{c}), 5 \mathrm{~mm}(\mathbf{e})$, $200 \mu \mathrm{m}(\mathbf{f}), 100 \mu \mathrm{m}(\mathbf{g}), 20 \mu \mathrm{m}(\mathbf{h})$. 
face-sterilised healthy-looking terminal root of P. oceanica, 17 June 2012, M.Vohník P09. Spain. Girona Province: L'Escala (42.10744N, 3.16892E), isolated from a surfacesterilised healthy-looking terminal root of P. oceanica, 18 June 2012, M.Vohník P20.

Habitat and distribution. Root mycobiont of the dominant and endemic Mediterranean seagrass Posidonia oceanica. So far known only from the NW Mediterranean Sea.

Notes. Both colonial morphotypes, named compact and mycelial, appeared on surface-sterilised root segments of $P$. oceanica and after inoculation also on solid agar media but the compact colonies with the cerebriform pattern formed only on the original root segments. All examined colonies of P. atricolor emerging from the original root segments developed from melanised microsclerotia formed exclusively intracellularly in the P. oceanica hypodermis (Figure $5 \mathrm{~d}, \mathrm{~h}$ ). The mycelial morphotype was observed on MMN and PCA, while compact colonies were formed on PDA and PCA (Vohník et al. 2016; this study). When the surface of a colony exhibiting the compact colonial morphotype was washed regularly with sterile tap water, fragments of hyphae were released to form minute daughter colonies (Figure 6e). These daughter colonies were either of a rhizoidal form composed of substrate mycelium and continued to develop the mycelial morphotype or they assumed the compact colony character from the beginning (Figure 6f). A new hypha was often formed through the globose swelling, regardless of its position on the hypha (Figures 6i-k).

\section{Discussion}

The microscopic screening of Posidonia oceanica root fungal colonisation confirms that the recently described DSE association (Vohník et al. 2015) formed by the Pleosporales sp. MV-2012 (Vohník et al. 2016) and introduced as Posidoniomyces atricolor in this study, is present at all investigated localities. The tag-encoded 454-pyrosequencing of fungal DNA extracted from surface-sterilised $P$. oceanica root segments confirms the dominance of this fungus in the root mycobiota of the dominant seagrass in the NW Mediterranean Sea. Our analysis of combined DNA sequences of nuclear ribosomal and protein-coding loci confirms the placement of P. atricolor in the Aigialaceae (Pleosporales, Dothideomycetes) and suggests an independent marine biotrophic lineage.

The root-symbiotic Posidoniomyces is related to mostly saprobic lignicolous marine fungi from estuarine environments colonising wood and roots of mangroves growing in tropical regions of both Eastern and Western Hemispheres, a situation resembling, at least to some extent, the relationship of the ubiquitous terrestrial root-symbiotic Rhizoscyphus ericae aggregate to saprobic fungi from the genus Hyaloscypha (Fehrer et al. 2019). Because mycorrhizal fungi from the $R$. ericae aggregate have significant saprobic abilities (Martino et al.2018), they can decompose recalcitrant peat and exchange mineral nutrients (especially nitrogen) for the host photosynthetically bound carbon. Since $P$. oceanica often grows on thick layers of recalcitrant peat-like matte (Figure $1 \mathrm{~b}$, c), which typically stores large amounts of organically-bound nutrients (Fourqurean et 
al. 2012) directly unavailable to plants (Read 1991), it is tempting to speculate about the possible role of $P$. atricolor in mineral nutrition of the dominant Mediterranean seagrass (also see Borovec and Vohník 2018; Kolátková and Vohník 2019). On the other hand, genomes of DSE fungi typically combine saprobic and pathogenic traits (Schlegel et al. 2016; Knapp et al. 2018) and effects of root endophytes on host plant fitness vary along the parasitism-mutualism continuum (Newsham 2011; Mayerhofer et al. 2013). Thus, although the specific association with $P$. atricolor is omnipresent in P. oceanica at all so far investigated localities, to date there is no solid proof that it is of any benefit to the seagrass.

The Aigialaceae (Suetrong et al. 2009) was erected for marine ascomycetes characterised by fisstunicate asci with a non-amyloid apex and a ring-like apical apparatus containing septate or muriform ascospores with a gelatinous sheath or cap, trabeculate hamathecium and non-stromatic, carbonatious to coriaceous, non-papillate ascomata. Additionally, Fissuroma and Neoastrosphaeriella occurring on bamboo, palms and flowering plants in terrestrial and freshwater environments were added to the family by Liu et al. (2011). The asexual morphs of marine species are generally unknown. The asexual morph of Fissuroma was reported as coelomycetous, pleurophomopsis-like (Tanaka and Harada 2005; Liu et al. 2011). Axenic cultures of $P$. atricolor remained sterile and two colonial morphotypes, named compact and mycelial, were consistently formed originating from the primary source. Although the presence of both morphotypes on PCA, a low sugar content medium, would suggest that the mode of nutrition does not influence the colony appearance, the absence of one or the other morphotype on MMN and PDA may indicate that the nutrition mode could play a role to some extent. When a compact colony was regularly washed with sterile tap water, a number of daughter colonies were formed all over the agar plate (Figure 6e), suggesting that liquid culture might be an efficient way for producing larger quantities of $P$. atricolor mycelium. These colonies usually assumed the form of a miniature rhizoidal-like colony (Figure 6f) formed mainly by submerged mycelium or they formed the welldistinguishable compact colonial morphotype directly. It is probable that the capitate swellings protruding above the surface of the compact colonies (Figure $6 \mathrm{~g}$, h) together with hyphal fragments act as propagules in the absence of conidia and ensure the dispersal of the fungus in a simulated environment. These terminal, intercalary and sometimes lateral mostly globose swellings resemble intercalary conidia of species of Knufia, e.g. K. perforans, formed on elongated and monilioid hyphae (Tsuneda et al. 2011). However, $P$. atricolor compact colonies have never been observed in vivo directly on $P$. oceanica roots and it is thus unknown whether the capitate swellings form and act as propagules also under natural conditions.

The Dothideomycetes include several marine genera that usually do not form an asexual state and are distributed in several orders, i.e. Capnodiales, Dothideales, Hysteriales, Jahnulales, Patellariales and Pleosporales, or incertae sedis lineages (Suetrong et al. 2009). They include mainly taxa thriving in intertidal zone on a variety of substrates of mangroves in tropics or less frequently on salt marsh plants in temperate regions. Other marine Dothideomycetes can occur as parasites or possible endophytes 
of seagrasses or marine macroalgae and are completely submerged. The omnipresence and dominance of $P$. atricolor in the roots of $P$. oceanica suggests a close symbiotic relationship with the dominant Mediterranean seagrass, a trait so far unparalleled in other Dothideomycetes. At the same time, to our knowledge, the characteristic DSE colonisation pattern of $P$. atricolor has never been observed in any other seagrass species, suggesting its specificity for P. oceanica (also see Discussion in Vohník et al. 2015).

The analysis of all available $P$. atricolor ITS sequences (Vohník et al. 2016, 2017; this study) revealed several aspects that may connect with their geographic distribution and possibly also the symbiotic lifestyle. The ITS1 region of $P$. atricolor contains ca. $294 \mathrm{nt}$ long insertion near the 5'-end when compared to ITS1 of other members of the Aigialaceae. Only four species of the whole family have their ITS sequences available; the ITS1 varies between 151-168 nt in Fissuroma (F. maculans, F. neoaggregatum) and between 186-201 nt in Neoastrosphaeriella ( $N$. aquatica, $N$. krabiensis), compared to $445 \mathrm{nt}$ in P. atricolor. When the ITS1, 5.8S and ITS2 of P. atricolor were checked for closest hits by the BLAST search in GenBank, the closest relatives for the 5.8S region were members of the Aigialaceae and other taxa of the Pleosporales; however, no close hits were revealed for ITS1 and ITS2. Since the ITS region was amplified and sequenced as a part of the whole nuc18S region with several forward and reverse primers, it is unlikely that this divergence was caused by PCR or sequencing errors. ITS is a rapidly evolving region where numerous insertions and deletions occur. Considering the probably obligate symbiotic lifestyle of $P$. atricolor in the host roots, the long insertion in ITS1 and high divergence in ITS2 sequences may be a result of co-evolution of both partners, higher gene flow rate and possibly horizontal gene transfer resulting in genetic mismatches in the fungal partner (Saikkonen et al. 2004, 2010; also see Kolařík and Vohník 2018). However, outside the Aigialaceae, the ITS1 region can be much longer, for example in Astrosphaeriella bambusae, the outgroup, it is $445 \mathrm{nt}$ long. On the other hand, the length of the ITS2 region is comparable between $P$. atricolor (188-192 nt) and other members of the Aigialaceae (156-163 nt).

Although the ITS sequences of all $P$. atricolor isolates are nearly identical (99.8798.99\% identity between the type strain BRK-21 and other isolates), they differ in up to six indels near the 5'-end of the ITS2. These site mutations can be used to some extent to characterise different populations of $P$. atricolor (Figure 4). Only strains which could be compared morphologically, i.e. those successfully derived from $P$. oceanica surface-sterilised root segments into axenic culture (Vohník et al. 2016; this study), were analysed. Their colony characters and colonisation pattern in the roots of the host were identical. At the ITS2 sequence level, we could distinguish populations from the north-west regions of the Mediterranean (France, Spain) and those from the northcentral part of the Adriatic coast (Croatia). Moreover, the Croatian population from Borak (locality HR-1; Table 1) seems to be a source of several mutations. Further screening of P. oceanica root mycobiota outside the NW Mediterranean is apparently needed to fully elucidate the usefulness of ITS sequences for distinguishing geographically different populations of $P$. atricolor.

Although it is a significant producer of biomass and an important source of decomposing organic matter in the sea and adjacent habitats, the mycobiota of $P$. oceanica has 
been studied only by a few authors (e.g. Kohlmeyer 1963; Cuomo et al. 1985; Panno et al. 2013; Gnavi et al. 2014; Vohník et al. 2016, 2017; this study), with differing results. Most significantly, no study prior to Vohník et al. (2016) reported $P$. atricolor in the mycobiota of the dominant Mediterranean seagrass. This is probably due to the manner of material sampling and isolation procedure, i.e. direct isolation from decaying plant matter vs. serially washed or surface-sterilised parts of living plants, the former often leading to detection of fast-growing surface-dwelling saprobes in contrast to isolation of true endophytes (Sieber 2002; also see Discussion in Vohník et al. 2016, 2017). Indeed, apart from $P$. atricolor and the obligate marine Sordariomycetes (Corollospora marina and C. intermedia in Microascales, Lulwoana sp. and Lulworthia sp. in Lulworthiales and Papulaspora halima incertae sedis) and Dothideomycetes (Halotthia posidoniae, Pontoporeia biturbinata and several other genera in Pleosporales), majority of the fungi reported from P. oceanica are asexually reproducing ubiquitous fungi (Panno et al. 2013).

The distribution pattern of $P$. oceanica mycobiota in leaves, rhizomes, roots and matte is affected by various environmental parameters, presence of growth-inhibiting substances in leaves or antagonistic organisms and may be also influenced by the season (Cuomo et al. 1985; Panno et al. 2013; Gnavi et al. 2014). However, no detailed data are yet available for the dominant root mycobiont $P$. atricolor, except that it seems to be restricted to $P$. oceanica roots. Mycorrhizal fungi form often vigorous extraradical mycelium penetrating the substrate far beyond the rhizosphere, thus forming the mycorrhizosphere (i.e. a volume of soil under a combined influence of the root and the emerging fungal hyphae) (Linderman 1988). The mycorrhizosphere significantly enlarges the volume of the substrate available for mycorrhizal nutrient uptake and in a way defines individual mycorrhizal types. It would therefore be interesting to screen the volume and enzymatic activity of the $P$. atricolor extraradical mycelium (if existing) to decide more precisely about the mode of the interaction between the dominant Mediterranean seagrass and its dominant root mycobiont.

\section{Conclusions}

This study confirms at an unprecedented scale that the diversity of the root mycobiota of the dominant Mediterranean seagrass is relatively narrow and dominated by a single pleosporalean fungus so far not known from any other hosts or environments. This fungus is introduced here as a new genus and species Posidoniomyces atricolor and resides as an independent marine biotrophic lineage in the Aigialaceae. The characteristic colonisation pattern of $P$. atricolor in $P$. oceanica roots has not been reported in any other seagrass and resembles colonisation by DSE fungi which are ubiquitous in terrestrial roots. Further research is needed on the distribution and genetic variability (especially ITS sequences) of $P$. atricolor in the rest of the Mediterranean Sea (i.e. Eastern Mediterranean Basin, the coast of North Africa). Additionally, given the uniquely discontinuous distribution area of the genus Posidonia (Green and Short 2003), targeted research on the root mycobiota of its Australian species would be of a special evolutionary significance. 


\section{Acknowledgments}

This study constitutes a part of long-term research projects of the Czech Academy of Sciences, Institute of Botany (RVO 67985939) and Charles University, Faculty of Science (MŠMT LO1417). Judith Fehrer stimulated the cooperation between MV and MR from the outset, Jiří Machač helped with the photo documentation, Mirka Opičková helped with the DNA isolations (all Inst. of Botany, Prủhonice), David Vondrášek (Charles Uni., Prague, CZ) helped with the sampling in France, Italy and Spain, Miroslav Kolař́k helped with preliminary phylogenetic analyses and Jana Vorríšková performed the pyrosequencing (both Inst. of Microbiology, Prague, CZ) and Ivan Župan (Zadar Uni., Zadar, HR) helped with obtaining a sampling permit issued by the Croatian Ministry of Environmental and Nature Protection (UP/I-61207/13-48/48//517-07-1-1-1-13-2) as well as with the sampling in Croatia; all these contributions are greatly appreciated. The authors thank Conrad L. Schoch and Kazuaki Tanaka (reviewers) and Huzefa Raja (editor) for the careful reading and suggestions which helped to improve this paper.

\section{References}

Altschul SF, Madden TL, Schäffer AA, Zhang Z, Zhang Z, Miller W, Lipman DJ (1997) Gapped BLAST and PSI-BLAST: a new generation of protein database search programs. Nucleic Acids Research 25: 3389-3402. https://doi.org/10.1093/nar/25.17.3389

Alva P, Mckenzire EHC, Pointing SP, Pena-Murala R, Hyde KD (2002) Do seagrasses harbour endophytes? In: Hyde KD (Ed.) Fungi in Marine Environments. Fungal Diversity Research Series. Hong Kong University Press, Hong Kong, 167-178.

Arnaud-Haond S, Duarte CM, Diaz-Almela E, Marbà N, Sintes T, Serrão EA (2012) Implications of extreme life span in clonal organisms: millenary clones in meadows of the threatened seagrass Posidonia oceanica. PLOS ONE 7: e30454. https://doi.org/10.1371/journal. pone.0030454

Bao D, Luo Z, Jeewon R, Nalumpang S, Su H, Hyde KD (2019) Neoastrosphaeriella aquatica sp. nov. (Aigialaceae), a new species from freshwater habitat in southern Thailand. Phytotaxa 391: 197-206. https://doi.org/10.11646/phytotaxa.391.3.3

Borovec O, Vohník M (2018) Ontogenetic transition from specialized root hairs to specific root-fungus symbiosis in the dominant Mediterranean seagrass Posidonia oceanica. Scientific Reports 8: 10773. https://doi.org/10.1038/s41598-018-28989-4

Bruzone MC, Fehrer J, Fontenla SB, Vohník M (2017) First record of Rhizoscyphus ericae in Southern Hemisphere's Ericaceae. Mycorrhiza 27: 147-163. https://doi.org/10.1007/ s00572-016-0738-8

Crous PW, Wood AR, Okada G, Groenewald JZ (2008) Foliicolous microfungi occurring on Encephalartos. Persoonia 21: 135-146. https://doi.org/10.3767/003158508X380612

Cuomo V, Vanzanella F, Fresi E, Cinelli F, Mazzella L (1985) Fungal flora of Posidonia oceanica and its ecological significance. Transactions of the British Mycological Society 84: 35-40. https://doi.org/10.1016/S0007-1536(85)80217-5 
De Falco G, Molinaroli E, Conforti A, Simeone S, Tonielli R (2017) Biogenic sediments from coastal ecosystems to beach-dune systems: implications for the adaptation of mixed and carbonate beaches to future sea level rise. Biogeosciences 14: 3191-3205. https://doi. org/10.5194/bg-14-3191-2017

den Hartog C (1970) Seagrasses of the world. North-Holland Publishing, the Netherlands.

Edgar RC (2013) UPARSE: highly accurate OTU sequences from microbial amplicon reads. Nature Methods 10: 996-998. https://doi.org/10.1038/nmeth.2604

Fehrer J, Réblová M, Bambasová V, Vohník M (2019) The root-symbiotic Rhizoscyphus ericae aggregate and Hyaloscypha (Leotiomycetes) are congeneric: Phylogenetic and experimental evidence. Studies in Mycology 92: 195-225. https://doi.org/10.1016/j.simyco.2018.10.004

Fourqurean JW, Duarte CM, Kennedy H, Marbà N, Holmer M, Mateo MA, Apostolaki ET, Kendrick GA, Krause-Jensen D, McGlathery KJ, Serrano O (2012) Seagrass ecosystems as a globally significant carbon stock. Nature Geoscience 5: 505-509. https://doi. org/10.1038/ngeo1477

Gardes M, Bruns TD (1993) ITS primers with enhanced specificity for Basidiomycetes - application to the identification of mycorrhizae and rusts. Molecular Ecology 2: 113-118. https://doi.org/10.1111/j.1365-294X.1993.tb00005.x

Gargas A, Taylor JW (1992) Polymerase chain reaction (PCR) primers for amplifying and sequencing nuclear $18 \mathrm{~S}$ rDNA from lichenized fungi. Mycologia 84: 589-592. https://doi. org/10.1080/00275514.1992.12026182

Gessner RV, Kohlmeyer J (1976) Geographical distribution and taxonomy of fungi from salt marsh Spartina. Canadian Journal of Botany 54: 2023-2037. https://doi.org/10.1139/b76-216

Giakoumi S, Sini M, Gerovasileiou V, Mazor T, Beher J, Possingham HP, Abdulla A, Çinar ME, Dendrinos P, Gucu AC, Karamanlidis AA (2013) Ecoregion-based conservation planning in the Mediterranean: dealing with large-scale heterogeneity. PLOS ONE 8: e76449. https://doi.org/10.1371/journal.pone.0076449

Gnavi G, Ercole E, Panno L, Vizzini A, Varese GC (2014) Dothideomycetes and Leotiomycetes sterile mycelia isolated from the Italian seagrass Posidonia oceanica based on rDNA data. SpringerPlus 3: 508. https://doi.org/10.1186/2193-1801-3-508

Green EP, Short FT (2003) World atlas of seagrasses. University of California Press, USA.

Hall TA (1999) BioEdit: a user-friendly biological sequence alignment editor and analysis program for Windows 95/98/NT. Nucleic Acids Symposium Series 41: 95-98.

Hemminga MA, Duarte CM (2000) Seagrass Ecology. Cambridge University Press, UK. https://doi.org/10.1017/CBO9780511525551

Huelsenbeck JP, Ronquist F (2001) MrBayes: Bayesian inference of phylogenetic trees. Bioinformatics 17: 754-755. https://doi.org/10.1093/bioinformatics/17.8.754

Jones EBG (1963) Marine fungi: II. Ascomycetes and deuteromycetes from submerged wood and drift Spartina. Transactions of the British Mycological Society 46: 135-144. https:// doi.org/10.1016/S0007-1536(63)80015-7

Jones EBG, Pang KL (2012) Marine fungi and fungal-like organisms. de Gruyter, Germany. https://doi.org/10.1515/9783110264067

Jumpponen A, Trappe JM (1998) Dark septate endophytes: a review of facultative biotrophic root-colonizing fungi. New Phytologist 140: 295-310. https://doi.org/10.1046/j.14698137.1998.00265.x 
Katoh K, Asimenos G, Toh H (2009) Multiple alignment of DNA sequences with MAFFT. Methods in Molecular Biology 537: 39-64. https://doi.org/10.1007/978-1-59745-251-9_3 Kauff F, Lutzoni F (2002) Phylogeny of the Gyalectales and Ostropales (Ascomycota, Fungi): among and within order relationships based on nuclear ribosomal RNA small and large subunits. Molecular Phylogenetics and Evolution 25: 138-156. https://doi.org/10.1016/ S1055-7903(02)00214-2

Knapp DG, Németh JB, Barry K, Hainaut M, Henrissat B, Johnson J, Kuo A, Lim JH, Lipzen A, Nolan M, Ohm RA (2018) Comparative genomics provides insights into the lifestyle and reveals functional heterogeneity of dark septate endophytic fungi. Scientific Reports 8: 6321. https://doi.org/10.1038/s41598-018-24686-4

Kohlmeyer J (1963) Zwei neuen Ascomycetes Gattungen auf Posidonia rhizomen. Nova Hedwigia 6: 5-13.

Kohlmeyer J, Kohlmeyer E (1971) Marine fungi from tropical America and Africa. Mycologia 63: 831-861. https://doi.org/10.1080/00275514.1971.12019172

Kohlmeyer J, Kohlmeyer E (1979) Marine Mycology. The higher fungi. Academic Press, USA. Kohlmeyer J, Volkmann-Kohlmeyer B (1991) Illustrated key to the filamentous marine fungi. Botanica Marina 34: 1-61. https://doi.org/10.1515/botm.1991.34.1.1

Kohlmeyer J, Volkmann-Kohlmeyer B (2001) The biodiversity of fungi on Juncus roemerianus. Mycological Research 105: 1411-1412. https://doi.org/10.1017/S095375620124547X

Kohlmeyer J, Volkmann-Kohlmeyer B (2002) Fungi on Juncus and Spartina: new marine species of Anthostomella, with a list of marine fungi known from Spartina. Mycological Research 106: 365-374. https://doi.org/10.1017/S0953756201005469

Kohout P, Sýkorová Z, Čtvrtlíková M, Rydlová J, Suda J, Vohník M, Sudová R (2012) Surprising spectra of root-associated fungi in submerged aquatic plants. FEMS Microbiology Ecology 80: 216-235. https://doi.org/10.1111/j.1574-6941.2011.01291.x

Kohout P, Malinová T, Roy M, Vohník M, Jersáková J (2013) A diverse fungal community associated with Pseudorchis albida (Orchideaceae) roots. Fungal Ecology 6: 50-64. https:// doi.org/10.1016/j.funeco.2012.08.005

Kolarík M, Vohník M (2018) When the ribosomal DNA does not tell the truth: The case of the taxonomic position of Kurtia argillacea, an ericoid mycorrhizal fungus residing among Hymenochaetales. Fungal Biology 122: 1-18. https://doi.org/10.1016/j.funbio.2017.09.006

Kolátková V, Vohník M (2019) Adaptive traits in the seagrass Posidonia oceanica: Root hairs with spiral cell walls, not spiral root hairs. Aquatic Botany 155: 52-53. https://doi. org/10.1016/j.aquabot.2018.11.013

Kóljalg U, Nilsson RH, Abarenkov K, Tedersoo L, Taylor AF, Bahram M, Bates ST, Bruns TD, Bengtsson-Palme J, Callaghan TM, Douglas B (2013) Towards a unified paradigm for sequencebased identification of fungi. Molecular Ecology 22: 5271-5277. https://doi.org/10.1111/ mec. 12481

Linderman RG (1988) Mycorrhizal interactions with the rhizosphere microflora: the mycorrhizosphere effect. Phytopathology 78: 366-371.

Liu JK, Phookamsak R, Jones EG, Zhang Y, Ko-Ko TW, Hu HL, Boonmee S, Doilom M, Chukeatirote E, Bahkali AH, Wang Y (2011) Astrosphaeriella is polyphyletic with species in Fissuroma gen. nov., and Neoastrosphaeriella gen. nov. Fungal Diversity 51: 135-154. https://doi.org/10.1007/s13225-011-0142-9 
Liu YJ, Whelen S, Hall BD (1999) Phylogenetic relationships among ascomycetes: evidence from an RNA polymerase II subunit. Molecular Biology and Evolution 16: 1799-1808. https://doi.org/10.1093/oxfordjournals.molbev.a026092

Lukešová T, Kohout P, Větrovský T, Vohník M (2015) The potential of Dark Septate Endophytes to form root symbioses with ectomycorrhizal and ericoid mycorrhizal middle European forest plants. PLOS ONE 10: e0124752. https://doi.org/10.1371/journal.pone.0124752

Martino E, Morin E, Grelet GA, Kuo A, Kohler A, Daghino S, Barry KW, Cichocki N, Clum A, Dockter RB, Hainaut M (2018) Comparative genomics and transcriptomics depict ericoid mycorrhizal fungi as versatile saprotrophs and plant mutualists. New Phytologist 217: 1213-1229. https://doi.org/10.1111/nph.14974

Marx DH (1969) Influence of ectotrophic mycorrhizal fungi on resistance of pine roots to pathogenic infections I. Antagonism of mycorrhizal fungi to root pathogenic fungi and soil bacteria. Phytopathology 59: 153-163.

Mason-Gamer RJ, Kellogg EA (1996) Testing for phylogenetic conflict among molecular data sets in the tribe Triticeae (Gramineae). Systematic Biology 45: 524-545. https://doi. org/10.1093/sysbio/45.4.524

Mayerhofer MS, Kernaghan G, Harper KA (2013) The effects of fungal root endophytes on plant growth: a meta-analysis. Mycorrhiza 23: 119-128. https://doi.org/10.1007/s00572012-0456-9

Miller MA, Pfeiffer W, Schwartz T (2010) Creating the CIPRES Science Gateway for inference of large phylogenetic trees. Proceedings of the Gateway Computing Environments Workshop, USA. https://doi.org/10.1109/GCE.2010.5676129

Newsham KK (2011) A meta-analysis of plant responses to dark septate root endophytes. New Phytologist 10: 783-793. https://doi.org/10.1111/j.1469-8137.2010.03611.x

Nielsen SL, Thingstrup I, Wigand C (1999) Apparent lack of vesicular-arbuscular mycorrhiza (VAM) in the seagrasses Zostera marina L. and Thalassia testudinum Banks ex Konig. Aquatic Botany 63: 261-266. https://doi.org/10.1016/S0304-3770(98)00123-5

Notarbartolo di Sciara G, Agardy T (2010) Overview of scientific findings and criteria relevant to identifying SPAMIs in the Mediterranean open seas, including the deep sea. UNEPMAP, Tunis.

Nylander JAA (2008) MrModeltest2 v. 2.3 (Program for selecting DNA substitution models using PAUP*). Evolutionary Biology Centre, Sweden.

Panno L, Bruno M, Voyron S, Anastasi A, Gnavi G, Miserere L, Varese GC (2013) Diversity, ecological role and potential biotechnological applications of marine fungi associated to the seagrass Posidonia oceanica. New Biotechnology 30: 685-694. https://doi. org/10.1016/j.nbt.2013.01.010

Phookamsak R, Norphanphoun C, Tanaka K, Dai DQ, Luo ZL, Liu JK, Su HY, Bhat DJ, Bahkali AH, Mortimer PE, Xu JC (2015) Towards a natural classification of Astrosphaeriella-like species; introducing Astrosphaeriellaceae and Pseudoastrosphaeriellaceae fam. nov. and Astrosphaeriellopsis, gen. nov. Fungal Diversity 74: 143-197. https://doi.org/10.1007/s13225-015-0352-7

Read DJ (1991) Mycorrhizas in ecosystems. Experientia 47: 376-391. https://doi.org/10.1007/ BF01972080

Reeb V, Lutzoni F, Roux C (2004) Contribution of RPB2 to multilocus phylogenetic studies of the euascomycetes (Pezizomycotina, Fungi) with special emphasis on the lichen-forming 
Acarosporaceae and evolution of polyspory. Molecular Phylogenetics and Evolution 32: 1036-1060. https://doi.org/10.1016/j.ympev.2004.04.012

Saikkonen K, Wäli PR, Helander M, Faeth SH (2004) Evolution of endophyte-plant symbioses. Trends in Plant Science 9: 275-280. https://doi.org/10.1016/j.tplants.2004.04.005

Saikkonen K, Wäli PR, Helander M (2010) Genetic compatibility determines endophyte-grass combinations. PLOS ONE 5: e11395. https://doi.org/10.1371/journal.pone.0011395

Sayers EW, Cavanaugh M, Clark K, Ostell J, Pruitt KD, Karsch-Mizrachi I (2019) GenBank.

Nucleic Acids Research 47: D94-D99. https://doi.org/10.1093/nar/gky989

Schlegel M, Münsterkötter M, Güldener U, Bruggmann R, Duò A, Hainaut M, Henrissat B,

Sieber CM, Hoffmeister D, Grünig CR (2016) Globally distributed root endophyte Phialocephala subalpina links pathogenic and saprophytic lifestyles. BMC Genomics 17: 1015. https://doi.org/10.1186/s12864-016-3369-8

Crous PW, Schoch CL, Hyde KD, Wood AR, Gueidan C, De Hoog GS, Groenewald JZ (2009a) A class-wide phylogenetic assessment of Dothideomycetes. Studies in Mycology 64: 1-15. https://doi.org/10.3114/sim.2009.64.02

Schoch CL, Sung GH, López-Giráldez F, Townsend JP, Miadlikowska J, Hofstetter V, Robbertse B, Matheny PB, Kauff F, Wang Z, Gueidan C (2009b) The Ascomycota tree of life: a phylum-wide phylogeny clarifies the origin and evolution of fundamental reproductive and ecological traits. Systematic Biology 58: 224-239. https://doi.org/10.1093/sysbio/syp020

Serrano O, Mateo MA, Renom P, Julià R (2012) Characterization of soils beneath a Posidonia oceanica meadow. Geoderma 185-186: 26-36. https://doi.org/10.1016/j.geoderma.2012.03.020

Sieber TN (2002) Fungal root endophytes. In: Waisel Y, Eshel A, Kafkafi (Eds) Plant roots - the hidden half, $3^{\text {rd }}$ edn. Marcel Dekker, USA. https://doi.org/10.1201/9780203909423.ch49

Slippers B, Boissin E, Phillips AJ, Groenewald JZ, Lombard L, Wingfield MJ, Postma A, Burgess T, Crous PW (2013) Phylogenetic lineages in the Botryosphaeriales: a systematic and evolutionary framework. Studies in Mycology 76: 31-49. https://doi.org/10.3114/sim0020

Stamatakis A (2006) RAxML-VI-HPC: maximum likelihood-based phylogenetic analyses with thousands of taxa and mixed models. Bioinformatics 22: 2688-2690. https://doi. org/10.1093/bioinformatics/btl446

Suetrong S, Schoch CL, Spatafora JW, Kohlmeyer J, Volkmann-Kohlmeyer B, Sakayaroj J, Phongpaichit S, Tanaka K, Hirayama K, Jones EB (2009) Molecular systematics of the marine Dothideomycetes. Studies in Mycology 64: 145-154. https://doi.org/10.3114/ sim.2009.64.09

Tanaka K, Harada Y (2005) Bambusicolous fungi in Japan (4): a new combination, Astrosphaeriella aggregata. Mycoscience 46: 114-118. https://doi.org/10.1007/S10267-004-0223-7

Tanaka K, Hirayama K, Yonezawa H, Hatakeyama S, Harada Y, Sano T, Shirouzu T, Hosoya T (2009) Molecular taxonomy of bambusicolous fungi: Tetraplosphaeriaceae, a new pleosporalean family with Tetraploa-like anamorphs, and notes on the phylogeny of selected species from bamboo. Studies in Mycology 64: 175-209. https://doi.org/10.3114/sim.2009.64.10

Tennakoon DS, Phookamsak R, Kuo CH, Goh TK, Jeewon R, Hyde KD (2018) Morphological and phylogenetic evidence reveal Fissuroma taiwanense sp. nov. (Aigialaceae, Pleospo- 
rales) from Hedychium coronarium. Phytotaxa 338: 265-275. https://doi.org/10.11646/ phytotaxa.338.3.4

Tsuneda A, Hambleton S, Currah RS (2011) The anamorph genus Knufia and its phylogenetically allied species in Coniosporium, Sarcinomyces, and Phaeococcomyces. Botany 89: 523-536. https://doi.org/10.1139/b11-041

Větrovský T, Baldrian P (2013) Analysis of soil fungal communities by amplicon pyrosequencing: current approaches to data analysis and the introduction of the pipeline SEED. Biology and Fertility of Soils 49: 1027-1037. https://doi.org/10.1007/s00374013-0801-y

Vilgalys R, Hester M (1990) Rapid genetic identification and mapping of enzymatically amplified ribosomal DNA from several Cryptococcus species. Journal of Bacteriology 172: 4238-4246. https://doi.org/10.1128/jb.172.8.4238-4246.1990

Vohník M, Albrechtová J (2011) The co-occurrence and morphological continuum between ericoid mycorrhiza and dark septate endophytes in roots of six European Rhododendron species. Folia Geobotanica 46: 373-386. https://doi.org/10.1007/s12224-011-9098-5

Vohník M, Sadowsky JJ, Kohout P, Lhotáková Z, Nestby R, Kolařík M (2012) Novel rootfungus symbiosis in Ericaceae: sheathed ericoid mycorrhiza formed by a hitherto undescribed basidiomycete with affinities to Trechisporales. PLOS ONE 7: e39524. https://doi. org/10.1371/journal.pone.0039524

Vohník M, Borovec O, Župan I, Vondrášek D, Petrtýl M, Sudová R (2015) Anatomically and morphologically unique dark septate endophytic association in the roots of the Mediterranean endemic seagrass Posidonia oceanica. Mycorrhiza 25: 663-672. https://doi. org/10.1007/s00572-015-0642-7

Vohník M, Borovec O, Kolařík M (2016) Communities of cultivable root mycobionts of the seagrass Posidonia oceanica in the northwest Mediterranean Sea are dominated by a hitherto undescribed pleosporalean dark septate endophyte. Microbial Ecology 71: 442-451. https://doi.org/10.1007/s00248-015-0640-5

Vohník M, Borovec O, Župan I, Kolařík M, Sudová R (2017) Fungal root symbionts of the seagrass Posidonia oceanica in the central Adriatic Sea revealed by microscopy, culturing and 454-pyrosequencing. Marine Ecology Progress Series 583: 107-120. https://doi. org/10.3354/meps 12337

Wanasinghe DN, Jeewon R, Jones EG, Boonmee S, Kaewchai S, Manawasinghe IS, Lumyong S, Hyde KD (2018) Novel palmicolous taxa within Pleosporales: multigene phylogeny and taxonomic circumscription. Mycological Progress 17: 571-590. https://doi.org/10.1007/ s11557-018-1379-4

White TJ, Bruns TD, Lee SB, Taylor JW (1990) Amplification and direct sequencing of fungal ribosomal RNA genes for phylogenetics. In: Innis N, Gelfand D, Sninsky J, White T (Eds) PCR - protocols and applications - a laboratory manual. Academic Press, USA. https:// doi.org/10.1016/B978-0-12-372180-8.50042-1

Yang T, Groenewald JZ, Cheewangkoon R, Jami F, Abdollahzadeh J, Lombard L, Crous PW (2017) Families, genera, and species of Botryosphaeriales. Fungal Biology 121: 322-346. https://doi.org/10.1016/j.funbio.2016.11.001 


\section{Supplementary material I}

Characteristics of fungal MOTUs obtained from surface sterilized Posidonia oceanica roots in this study

Authors: Martin Vohník, Ondřej Borovec, Zuzana Kolaříková, Radka Sudová, Martina Réblová

Data type: species data

Copyright notice: This dataset is made available under the Open Database License (http://opendatacommons.org/licenses/odbl/1.0/). The Open Database License $(\mathrm{ODbL})$ is a license agreement intended to allow users to freely share, modify, and use this Dataset while maintaining this same freedom for others, provided that the original source and author(s) are credited.

Link: https://doi.org/10.3897/mycokeys.55.35682.suppl1

\section{Supplementary material 2}

A list of fungi, isolate information and new sequences determined for this study (in bold) and additional sequences retrieved from GenBank

Authors: Martin Vohník, Ondřej Borovec, Zuzana Kolaříková, Radka Sudová, Martina Réblová

Data type: species data

Copyright notice: This dataset is made available under the Open Database License (http://opendatacommons.org/licenses/odbl/1.0/). The Open Database License (ODbL) is a license agreement intended to allow users to freely share, modify, and use this Dataset while maintaining this same freedom for others, provided that the original source and author(s) are credited.

Link: https://doi.org/10.3897/mycokeys.55.35682.suppl2 